\title{
Bocatius orvosi tárgyú versei
}

\author{
Balegová, Jana dr. ${ }^{1}$. Šimon, František dr. ${ }^{1}$ - Magyar László András dr. ${ }^{2}$ \\ ${ }^{1}$ Kassai P. J. Šafárik Egyetem, Bölcsészettudományi Kar, Román és Klasszikus Nyelvek Tanszék, Košice (Kassa) \\ ${ }^{2}$ Semmelweis Orvostörténeti Múzeum, Könyvtár és Levéltár, Budapest
}

Bocatius János vagy pontosabban Johannes Bock, latinos nevén Johannes Bocatius (Vetschau, Németország, 1569 - Uherský Brod, Csehország, 1621) jelentős - szorb nemzetiségü - humanista költő, diplomata és pedagógus volt. 1590-tól kezdve Észak-Magyarországon mint az eperjesi városi iskola rektora, majd 1603 és 1604 közt mint kassai városi fóbíró tevékenykedett. 1596-ban II. Rudolf (1552-1612) német-római császár és magyar király „poeta laureatus Caesareus” (császári koszorús költő) címmel tüntette ki, majd 1598-ban magyar nemességet is adományozott neki. Bocskai István (1557-1606), a Habsburg-ellenes felkelést vezető erdélyi fejedelem utóbb diplomáciai megbízatással küldte Németországba a protestáns fejedelmekhez, ahol a braunschweigi választó letartóztatta és kiszolgáltatta a császárnak. Prágában több évet töltött tömlöcben, 1611-ben sikerült megszöknie. A császári kegyelem elnyerése után visszatért Kassára. Innen hívta meg Bethlen Gábor (1580-1629) erdélyi fejedelem a gyulafehérvári könyvtár élére, $\mathrm{s}$ adott neki egyben történetírói megbízást. Bocatius újabb diplomáciai küldetése során hunyt el a magyar-morva határ "Magyar gázló” (ma: Uherský Brod, Csehország) néven ismert helységében.

Johannes Bocatius igen termékeny költő volt [1], aki, egyebek közt, orvosi tárgyú verseket is írt. 1599-ben Bártfán (Bardejov) publikálta terjedelmes Hungaridos libri poematum quinque címú versgyüjteményét [2]. A gyứjtemény második könyve tartalmazza disztichonokban írt Laus medicinae (Az orvostudomány dicsérete) címú enkómiumát. Ennek teljes címe a következő: „Laus medicinae ex dicto Ecclesiastici 38: Honora medicum propter necessitatem, quia Dominus eum fecit. Ad Magn[ificum] et Excell[entem] V[irum] D[ominum] Nicolaum de Bucellis, Ital[um], olim Steph[ani] r[egis] Pol[onici] Archiatrum, Med[icinae] Doctorem, Cracoviae. (Az orvostudomány dicsérete Sirák 38.1. szerint: „Tiszteld az orvost, mert jó szolgálatot tesz, meg hát az orvos is Isten teremtménye." A Nagyságos és Kiváló olasz Nicolaus Bucella Úr, István lengyel király egykori fóorvosa, krakkói orvosdoktornak ajánlva.) A költemény a medicinát és az orvosokat magasztalja, ám arra is felhívja a figyelmünket, hogy sorsunk valójában Isten kezében van.

Az olasz Niccolò Bucella (1520-1599) kiváló orvos volt, Báthory István (1533-1586) korábbi erdélyi feje- delem, lengyel király háziorvosaként is múködött. Weszprémi szerint Bucella az ősi magyar fönemesi Forgách család tagjait is kezelte, márpedig Bocatiust remek kapcsolatok füzték a családhoz [3].

Az orvostudomány dicséretének ötlete nyilván a neves elődöktől, például Rotterdami Erasmustól (1466-1536) származott, aki Löwenben, 1518-ban publikálta saját Encomium medicinae-jét [4]. A XVI-XVII. században általában ez a mú szolgált a hasonló tárgyú enkómiumok mintájául, egyebek közt Philippus Melanchton (14971560) számára is, aki két medicinadicséretet is írt Laus artis medicinae, illetve Encomium medicinae címmel [5]. Eobanus Hessus (1488-1540) pedig Erasmus enkómiumát szedte elégikus disztichonokba $[6,7]$.

Bocatius himnusza, amint az címéből is kitűnik, a bibliai Sirák könyvének 38. fejezetén nyugszik (1-15), amely azt taglalja, miért és miként érdemes orvoshoz fordulni. Ugyanezt az ótestamentumi helyet idézi egyébként Erasmus, Hessus vagy Melanchton is a maga művében. A szerző az ősi, mitikus orvosokkal, Aszklépiosz fiaival, Podaleiriosszal és Makháónnal kezdi versét, illetve arra a tiszteletre hivatkozik, amelyet az ókoriak az orvosok és a gyógyszerek iránt tanúsítottak, s aminek a medicina vélt isteni eredete volt az oka.

Inventumque Dei quod crederet esse medentis aetas pisca fuit grata memorque magis.

Hinc medicos opibus magnis et honoribus auxit, insertos claro iussit et esse loco.

Non paucis grandeis passim statuere columnas, pharmaca vel sancti numinis instar erant.

Et merito: aegrotis qui scit bene reddere vireis, is certe magno dignus honore vir est.

Gyógy-isten leleményének hitték eleink még, s tisztelték is ezért egykor a gyógytudományt.

Nagy jutalommal halmozták, nagy rangra emelték, becsben tartva, amint illik, az orvosokat.

Némelyiküknek az ókorban még kultusza is volt, sgyógyszereik csodaként vette az egyszerü nép.

$S$ jól is tette, hisz azt, ki a kórt gyógyitani képes, méltán illeti mély tisztelet és köszönet. 
Véleménye szerint az orvos kivételezett helyzete Isten adománya, ez az alapvető oka annak, hogy tisztelnünk kell őket:

Ut doctor praestet medicaminis, efficit ipse, a quo nostra venit vita salusque, Deus

His igitur coelum quod honores destinat altos, clarat Apollineos gloria iure viros

Üdvözitönk és életadónk, Isten, ki megáldja orvosainkat a szent gyógy-tudománnyal. Ezért, minthogy a tiszteletük mennyböl ered, öket Phoebus papjaiként hódolat illeti meg.

Bocatius felhívja figyelmünket azoknak a múveletlen embereknek az irigységére és hálátlanságára az orvosokkal szemben, akiknek bizalmatlansága azon alapul, hogy az orvos nem képes az életet meghosszabbítani.

Iam, licet egregii, vano ludibria vulgo sunt medici, et laudes nescit Apollo suas

Livor edax illos manet, obtrectatio carpit, Doctus et arte potens stellio nomen habet.

Clamor it: an medicus faceret mibi grandius aevum, Horas ipse sibi proroget ante suas.

Bármi derék is az orvos, csak gúnyolja a köznép, nem jár hála sosem fáradozásaiért,

Aljas irigység kezdi ki ót, mocskolja gyalázat. Nagy tudományú? Nekik csak locsogó-fecsegö.

Kérdezik ót gonoszul: Ha halandó vagy magad is, hogy nyújthatnád meg az én nagy becsü életidöm?

Bocatius elutasítja ezt a hozzáállást, és hangsúlyozza: az orvos dolga csupán annyi, hogy megtartsa vagy visszaadja az emberek egészségét, míg életről és halálról egyedül Isten dönthet.

Turba tace, non est ea noxa Machaonis, annos ille dat integros, caetera numen agit

Hallgass, ostoba had! Nem az orvos dönt a halálról. Testedet óvja csak ô: rólad az Isten itél.

Bocatius elítéli azt is, ha különféle tudatlan alakok adják ki magukat orvosnak és járatják le az orvosi hivatást:

Quin etiam passim vult quilibet esse Machaon sartor, fartor, anus, mysta, scholarcha rudis.

Sic ars vera iacet contempta, et nescia recti natio, iudicio privat honore bonos.

Már boldog s boldogtalan itt doktor lehet: ócska kókler, tornatanár, varga, szabó, banya is.

Sárban a szent tudomány: a tudatlanság diadalt ül, jókat is elszédit, hogyha a rossz sikeres.
Az ótestamentumi Sirák szavaival követel több tiszteletet az orvosnak:

Hos, inquam, hos, quamvis ringatur plurimus, aequum est, inter honorandos nomen habere viros.

Et pia Siracide medicos quia scita celebreis Suscipere, et magna tolleve laude iubent

Még ha gyalázzák is, mondom: tiszteld csak az orvost, méltán illeti meg tisztelet és becsület.

Vésd a Sirák próféta szavát az eszedbe, mely igy szól: „Tiszteld, s tartsd, ha tudós, nagyra az orvosodat!”

Az orvosok megítélésének követendő példájaként említi a Forgách családot, amelynek tagjai e bibliai parancsokat követik:

Forgaciana domus monitis his applicat aureis Vult medicos, certus porro sequatur honos.

Lám az egész Forgách-nemzetség hallgat e szóra, s orvosait mindig megfelelón becsïli.

Himnusza címzettjéhez, Niccolò Bucellához fordulva hangsúlyozza: méltatni kívánja orvosi tudományát, s erősen reméli, hogy Bucella tényleg képes enyhíteni betegei szenvedésén. Költeményében, némi túlzással, Hippokratészhez, Aszklépiosz mitikus fiához, Podaleirioszhoz, sőt magához Apollónhoz hasonlítja őt:

Huc te Sarmaticis nuper devexit ab oris Corpora quo fidei crederent aegra tuae.

Quae, precor, ut releves feliciter, arte reservas, Ut posthac semper membra valere queant.

O Bucella, tuam, celeberrime, grandibus artem Ad coelum vates laudibus usque feram.

Hippocrates alter, Podalirius alter, Apollo Alter eris noster tempus in omne solo.

Szarmata földröl érkeztél hozzánk, hogy a testünk rád bizhassuk akár épen, akár betegen.

Óvja egészségünk sörizze tovább medicinád, kérlek, s szervezetünk meg ne gyötörje a kór!

Ó Bucella, igaz költôként nagy tudományod mennybe menesztem majd, szípbeli hála gyanánt:

Második Hippokratész, Podaleiriosz és nagy Apollón, korszakod éke leszel szerte a földkerekén!

Végül felhívja figyelmünket arra a tiszteletre és bizalomra is, amellyel Báthory István lengyel király viseltetett Bucella iránt, majd enyhe túlzással Nesztórénál is hoszszabb életet kíván neki.

Sed, venerande senex, quoniam tibi tempore nostro Non habeat medicum Sarmatis ora parem 
Quod Stephanus rex Bathorea de stirpe professus,

Quando tibi corpus crederet ipse suum,

Quum quoque mortalis tu sis: pia numina poscam, Dent, superes Pylium Nestora in orbe senex

Ebben a században doktorból, bölcs öreg, egy sincs szarmata foldön olyan, mint te! Nem is lesz olyan!

Báthory István is rád bizta bajában a testét, hogy mire s mennyire tart, igy bizonyitva neked.

$S$ bárha halandó vagy, kérem könyörögve imámban, Nesztór éveit is hagyja le életidöd!

Bocatius költeménye tipikus orvos- és orvostudomány-magasztaló enkómium. Paradox módon Niccolò Bucella, a jókívánságok ellenére, még az enkómium megjelenésének évében elhunyt.

A másik orvosi tárgyú Bocatius-vers a Sirák könyve, 1596-ban kiadott parafrázisának negyedik könyvében, „De morbis” (II. Elégia. A betegségekről) címmel látott napvilágot [8]. Bár első pillantásra úgy tûnhet, mintha különféle betegségekről szólna, valójában csak arra vonatkozóan ad tanácsokat, hogyan viselkedjék az ember, ha beteg. Bocatius szerint Istenhez kell segítségért fordulnia s el kell fordítani elméjét a gonosz gondolatokról.

Prima tibi fuerit superum bene cura litandi

Placatus rediit corpora firma Deus.

Mentem averte malis, et crimina corde repellas.

Engeszteld meg az égieket, legelőbb, ha bajod van: Égi Urunk, ha segit, tested is ép lesz, erös.

Vesd el a rosszat, a szivedböl uzd messze a vak bünt,

Isten ekkor bizonyosan segíteni fog:

Est opus ad miseros currere dulce Deo Digna favore venit maiore cupido levandi Maior, et a coelo praemia certa feret.

Sit quicunque volet dives, tollatque querelas, Quod vix membra gravi pressa dolore trabat.

s lám szives sörömest óvja a tested Urunk.

Ám aki méltóbb rá, annak több jut ki kegyéböl, s azt bövebb jutalom várja, ba bajba keriul, gazdag lesz a szegény, s nem jajgat már soha többé az se, kinek testét megnyomoritja a kin.

A betegnek azért érdemes orvoshoz is fordulnia:

I pete Poeonia medicus cito gnarus in arte Tentet Apollinea parte levare malum.

Jöjön csak sebesen ki szakértő doktor, Apollón szent tudományával hátha segit a bajon.
$\mathrm{Az}$ egészséges elme és test ugyanis értékesebb az aranynál:

Corpus et ingenium sospes mihi gratius auro: Ditia quam misere corpora morbus habet.

Nam ego laetitiam, plus illa exposco secundam, Non mibi sit maius quicquid hic orbis habet.

Testem-lelkem olyan kincs, mely drágább az aranynál: Mily nyomorult lebet egy gazdag a kin közepett!

Boldogság se lehet nálánál lényegesebb, hisz nincs kincs nála nagyobb széles e földkerekén.

A szerző meglepő véleménye szerint néha jobb meghalni, mint testi bajainkkal kínlódni:

Luce carere aegram praestet quam ducere vitam Grata loco tristi mors properata venit.

Inkább haljak meg, minthogy betegen nyomorogjak, Óhajtott a halál, hogyha a lét szomorú.

Bocatius szerint sem isteni, sem orvosi segítséggel nem érhető el a teljes egészség, vagyis az orvostudomány nem mindenható [9].

Bocatius, akárcsak humanista társai, számos ismert emberrel, köztük egy sor orvossal levelezett vagy állt személyes kapcsolatban. Sokuknak írt hosszabb-rövidebb versikéket, például Jeszenszky Jánosnak (1566-1621), a magyarországi gyökerű, tragikus sorsú orvosnak, a sziléziai orvos-költő Caspar Cunradnak (1570-1633), Ezekiel Piperellnek, Erhard Placerusnak és Andreas Curtiusnak is - utóbbiak Magyarországon múködő olasz orvosok voltak.

Ezechiel Hebsacher eperjesi lelkésznek, a „Novus annus” (Bártfa, 1599) címü gyưjtemény függelékében, újévi jókívánságképpen, egy 11 disztichonból álló „költői imáját” ajánlotta a szerző abból az alkalomból, hogy Hebsacher Georg Fabusch (múk.: 1590-1617) eperjesi doktor gondjaira bízta magát [2].

A költemény két orvos találkozásával kezdődik, az egyik lelki, a másik testi betegségeket gyógyít. Ez után kiderül, mi az orvosok célja, milyen módszerekkel kezelik betegeiket: mindkettejük közös célja azonban a gyógyítás.

Convenere duo medici, quorum haud tamen una est Conditio, ast decus est huius et huius idem

Iste animas curare solet, sed corpus hic, ambo Dant miseris medica pharmaca certa manu.

Két orvos jött össze, habár más szakterületről, mindkettó jeles és fontos ügyet felügyel:

Lelkeket orvosol ez, mig testet amaz, de szakértón nyújt nyomorultaknak mindegyik enybületet. 
Bocatius azt kéri Krisztustól, „a lelki és testi medicina atyjától”, hogy a két orvos képes legyen együtt tevékenykedni, hiszen csak kettejük együttmúködése teheti nagygyá a medicinát.

Corporis atque animae medicinae, o Christe, repertor, Alter ut alterius, da, modo vivat ope.

Mutua et amborum sic ars te, vere Machaon, Laude super terras et super astra vehet.

Lelki s a testi bajok gyógyitásának atyja te, Krisztus, add, hogy az egyik a mást célba segitse, ha kell.

Kettejük eggyé vált tudománya emel csakis orvost dicsben a többi fölé, messze a csillagokig.

Bocatius három versét ajánlotta Spillenberger Sámuelnek, a neves lőcsei orvosnak (1573-1654). Az első epigramma „Hexasticha votiva” (Bártfa, 1612) [10] címü versgyüjteményében szerepelt (II. 701.):

Fratrum fervide amor, Spillenbergere, novorum Hungara cui medicum non habet ora parem:

Parvula in haec multam do pyxide dona salutem, Pandorae insanam, sed cave, inesse, putes.

Dispeream idque male, fratrum carissime, salvum Te mea si nolint vota tuosque, vale.

Spillenberger, drága barát, szívböl szeretett társ, jobb doktort, akinél nem követelhet e hon.

Itt e szelence ajándékképp, élvezd ezer évig, ám ki ne nyisd: benn tán Pandora átka lapul.

Ámbár esküszöm, én sose adnék drága barátom, benne olyat, mi neked vagy tieidnek is árt.

Lehetséges, hogy itt egy valóságos ajándék (szelence, pixis) feliratáról van szó, ám az is lehet, hogy a vers csak a múfaj szabályait követi. Spillenberger jelentőségét jelzi, hogy Bocatius Magyarországon páratlan orvosnak titulálja ơt. Ez a jelző nyilván részben költői túlzás, ám azért valamiféle alapjának kellett lennie. Hiszen Spillenberger nem véletlenül nyerte el Szepes megye „fizikusi” posztját 1612-ben, Bocatius verseskönyvének megjelenési évében.

Bocatius Spillenberger és Klementis Magdaléna esküvőjének tiszteletére is önálló verseskötetet adott ki, mégpedig „Bellaria Poetica” címmel [11]. Bocatius ebben egy Epithalamiont (nászéneket) is közölt, "Aliud ad Thalasionem" (Másik dal Thalasionak) címmel. A szerző ebben azt kérdezi Thalassius (gör. Hümen) római nászistentől, mit kérjen az egybekelteknek. Thalassius olyan, nászéjszakával kapcsolatos válaszokat ad, amelyek Bocatius és Spillenberger igen szoros baráti kapcsolatára utalnak. Például:

Doctorissa, meum venito in hortum, bunc hortum Veneris, datum benignos, nostras Ludia Magdalena, ludos.
Vestem deproperes, meum cor, et mel, vestem deproperes (refibulatus en Mavors ego primus), o meum cor... Hoc et scande cupile nuda nudo, nudinus Veneris quod imperator vult concurrere sic movere et arma.

Doktorném, gyere, látogass e kertbe, Vénusz kertje ez itt, abol mi játsszuk játékunk, kicsi Magdaléna drágám! Dobd hát messze rubád, szívem szerelmem, dobd hát messze rubád (vagy én dobom le elsöként, gyönyörüm, s leszek csupasz Mars)... Bújj hozzám csupaszon csupasz szinembez, Vénusz ünnepe jö, s a hadvezéred szétrobbantja a hév: csatázni kiván.”

A gyújtemény harmadik verse is kétértelmü erotikus utalásokban gazdag. Címe Girgillus (esetlen alak), formája disztichon és egy Spillenberger nevére (Spiel-inBerg), illetve a Spiel/Spule (német játék, illetve gombolyag, orsó) épített szójátékon alapul.

Aut lusum, aut fusum, fers et cognomine montem, uxoris fusus res tua lusus amor.

Et lusum et fusum Veneris vos monte beati exercete, sinat currere Parca diu.

Vénuszi játék (orsó tán?), meg hegy, mi nevedben rejlik: ez asszonyodé, az meg (a kéj) a tied.

Adja a sors, hogy az orsóból-kéjböl elegendo" jusson néktek, amig éltek e szép hegyeken.

Összegzésképpen megállapíthatjuk, hogy Bocatiusnak, mint kortársai zömének, mindenról, így az orvostudományról is megvolt a maga véleménye. Számos orvosi tárgyú verse bizonyítja, hogy hasznos tevékenységük miatt mélyen tisztelte az orvosokat. Közülük csak a képzetteket becsülte, akiket a görög mitológia nagyjaihoz hasonlított, míg a sarlatánokat elítélte. Minden tisztelete ellenére azonban azt ajánlotta, hogy betegség esetén mindenekelőtt Istenhez fohászkodjunk. A lelki és testi egészség egyensúlyán alapuló egészség megőrzésében az orvosok szerepét fontosnak tartotta, ám a medicina mindenhatóságáról egyáltalán nem volt meggyőződve.

\section{Irodalom}

[1] Bocatius, J.: The complete poetical works. [Opera quae exstant omnia poetica.] 1, 2. Ed. Csonka, F. Akadémiai Kiadó, Budapest, 1990. [Latin]

[2] Bocatius, J.: Five books of Hungarian poems. [Hungaridos libri poematum quinque.] Jacobus Klöss, Bartphae, 1599. [Latin]

[3] Weszprémi, I.: Short biographies of Hungarian and Transylvanian physicians. [Succincta medicorum Hungariae et Transilvaniae Biographia.] Centuria tertia, decas I. at II. Trattnern, Viennae, 1787 (reprint: Budapest, 1970). [Latin] 
[4] Erasmus von Rotterdam: The praise of medicine. [Encomium artis medicae - Lob der Heilkunst.] Ed., transl. Bergdolt, K. Manutius Verlag, Heidelberg, 2008. [Latin and German]

[5] Melanchthon, Ph.: The praise of medical art. The praise of medicine. [Laus artis medicae, Encomium medicinae.] In: Opera quae supersunt. Vol. XI. Ed. Bretschneider C. G. Schwetschke et fil., Schwäbisch Hall, 1843, col. 191-202. [Latin]

[6] Hessus, E.: The praise of medicine. [Laus medicinae.] In: Operum farragines duae. Schwäbisch Hall, 1539, 78a-108b. [Latin]

[7] Double-faced medicine. H. C. Agrippa: Satire on medicine. Erasmus: The praise of medicine. Ed. and transl. by L. A. Magyar. [Kétarcú orvostudomány. H. C. Agrippa: Szatíra az orvosokról, Erasmus: Az orvostudomány dicsérete. (Szerk., ford., bev. Magyar, L. A.).] Kalligram, Pozsony, 2002. (Hungarian)

[8] Bocatius, J.: Sirachs or Ecclesiasticus of Jesus, son of Sirach. [Siracides vel Ecclesiasticus Jesu, filii Sirach.] Wittenberg, 1596. [Latin]
[9] Taranová, E.: Ioannes Bocatius and his poem De morbis. [Ján Bocatius a jeho elégia De morbis.] In: Dimenzie jazykového vzdelávania v nefilologických odboroch (Tradícia a súčasnost'). UK, Bratislava, 2013, 195-199. [Slovak]

[10] Bocatius, J.: Votive hexasticha. [Hexasticha votiva.] Kléz, Bartpha, [1612]. [Latin]

[11] Bocatius, J.: Poetical sweetmeats. [Bellaria poetica.] Ioannes Festus, Cassoviae, 1616. [Latin]

(Magyar László András dr., Budapest, Török u. 4., 1023 e-mail: magyarlaszlo@upcmail.hu)

\section{Ellen Notbohm-Veronica Zysk} EZEREGY NAGYSZERRUU ÖTLET AUTIZMUSSAL ÉLŐ VAGY ASPERGER-SZINDRÓMÁS GYEREKEK NEVELÉSÉHEZ ÉS TANITTÁSÁHOZ

„Ha minden iskolában és családban a könyvben szereplő ötletek kis töredékét felhasználnák, beláthatatlan lehetöségek nyilnának meg elöttünk, hogy javítsuk az autizmussal vagy Asperger-szindrómával élö gyermekek életminőségét. Ez pedig csodálatos dolog!"

A könyv számtalan azonnal alkalmazható ötletet

Dr. Temple Grandin kínál szülőknek és nevelőknek az alábbi területeken:

- szenzoros integráció: fejlesztőfeladatok a szabadban és bent,

- kommunikáció: szóhasználat, hallás, vizualitás, környezet,

- viselkedés: tipikus viselkedési formák és kezelésük,

- mindennapi élet: ötletek a mindennapi szituációkhoz, a biztonság megteremtéséhez,

- szociális létezés: barátság, játék, kooperáció, érzelmek.

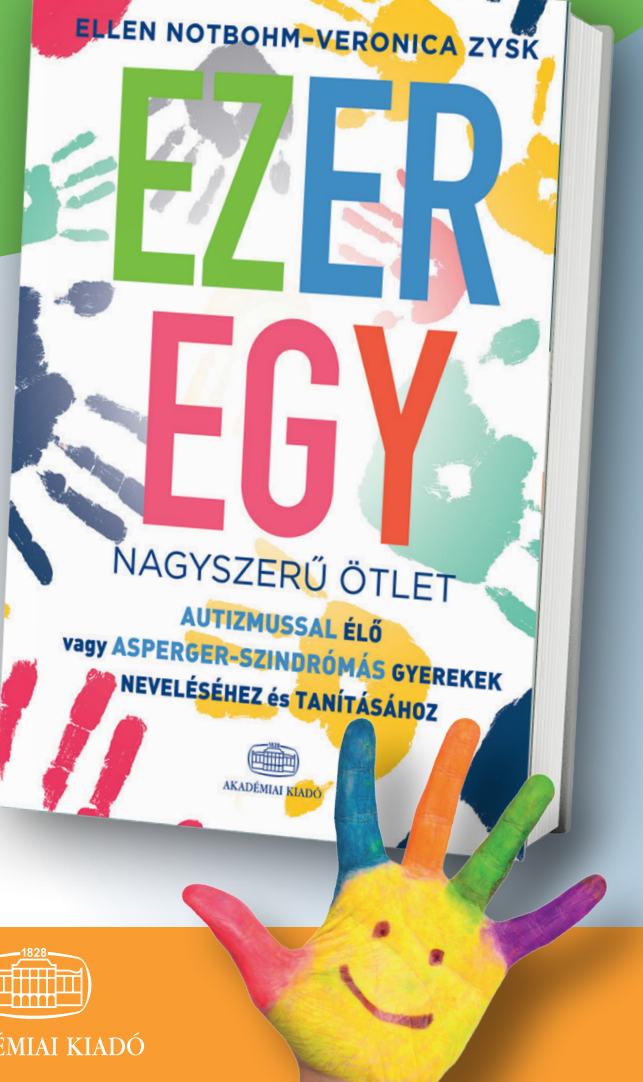

